\title{
EFEK PENAMBAHAN PROPILEN GLIKOL ALGINAT DAN ISOLAT PROTEIN KEDELAI TERHADAP MUTU FISIK DAN MUTU PENERIMAAN MI JAGUNG
}

\author{
[Effect of Propylene Glycol Alginate (PGA) and Soy Protein Isolate Addition \\ on the Physical Quality and Acceptance of Corn Noodles]
}

\author{
Fahim Muhammad Taqi ${ }^{1,2)}$, Subarna ${ }^{1,2)}$, Tjahja Muhandri ${ }^{1,2) \star}$, dan Rarasati Clorinita Utomo ${ }^{1)}$ \\ 1) Departemen IImu dan Teknologi Pangan, Fakultas Teknologi Pertanian, Institut Pertanian Bogor, Bogor \\ 2) Southeast Asian Food and Agricultural Science and Technology (SEAFAST) Center, Institut Pertanian Bogor, Bogor
}

Diterima 26 Juni 2018 / Disetujui 16 November 2018

\begin{abstract}
Corn noodle is a potential product to be developed in non-wheat producing countries; however the texture is generally less preferred than wheat noodles. The addition of propylene glycol alginate (PGA) and soy protein isolate (SPI) to the dough was expected to decrease the hardness of corn noodles and increase its protein content. This study aimed to evaluate the effect of PGA $(0,0.25,0.5,0.75$, and $1 \%)$ and SPI $(0,5$, and 10\%) addition on corn noodle rheology. Five parameters were analyzed i.e. cooking loss, elongation, hardness, cohesiveness and stickiness. A hedonic rating test was also performed to evaluate the corn noodle organoleptic quality. The results showed that the addition of PGA decreased the cooking loss and hardness, but increased the elongation and cohessiveness. While the addition of SPI decreased the cooking loss and cohessiveness (atPGA level 0 and $0.25 \%$ ), it increased hardness and elongation (at PGA level 0\%). Based on the hedonic test, corn noodle with $0.5 \%$ PGA without the addition of SPI was the most preferred formula.
\end{abstract}

Keywords: corn noodle, physical quality, PGA, SPI

\section{ABSTRAK}

Mi jagung merupakan produk yang berpotensi untuk dikembangkan di negara yang tidak mempro duksi gandum, meskipun memiliki sifat yang lebih keras dibanding mi terigu. Penggunaan propilen glikol alginat (PGA) dan soy protein isolate (SPI) diharapkan mampu menurunkan kekerasan mi jagung dan meningkatkan kandungan protein di dalamnya. Penelitian ini bertujuan mengevaluasi pengaruh penam bahan PGA $(0 ; 0,25 ; 0.5 ; 0,75$ dan $1 \%)$ dan SPI $(0,5$ dan $10 \%)$ terhadap reologi mi jagung. Analisis dilakukan terhadap 5 respon yaitu kehilangan padatan akibat pemasakan (KPAP), elongasi, kekerasan, ke kenyalan dan kelengketan. Uji rating hedonik dilakukan untuk mengevaluasi tingkat penerimaan panelis. Hasil penelitian menunjukkan bahwa penambahan PGA dapat menyebabkan penurunan KPAP, kekeras an, dan kelengketan, tetapi meningkatkan elongasi serta kekenyalan. Penambahan SPI tidak hanya me nyebabkan penurunan KPAP, dan kelengketan (pada level PGA 0 dan 0,25\%), akan tetapi penambahan tersebut juga dapat meningkatkan kekerasan dan elongasi (pada level PGA 0\%). Berdasarkan hasil uji sensori, formula yang paling disukai adalah yang dibuat dengan penambahan PGA $0,5 \%$ tanpa penam bahan SPI.

Kata kunci: mi jagung, mutu fisik, PGA, SPI

\section{PENDAHULUAN}

Riset tentang teknologi pembuatan mi berbahan baku $100 \%$ tepung jagung telah dikembangkan oleh beberapa peneliti. Muhandri et al. (2011) menggunakan teknik ekstrusi dengan ekstruder pemasakpencetak menghasilkan mi jagung dengan mutu yang bagus yaitu memiliki nilai kehilangan padatan akibat pemasakan (KPAP) yang rendah dan elonga-

*Penulis Korespondensi:

E-mail: cahyomuhandri@yahoo.com si yang tinggi, namun memiliki nilai kekerasan yang sangat tinggi yaitu sebesar 3039,79 gF. Subarna dan Muhandri (2013) melakukan pembuatan mi jagung dengan teknik kalendering menghasilkan mi dengan kekerasan yang rendah tetapi kelengketan yang cukup tinggi.

Beberapa jenis bahan tambahan pangan telah diteliti dan mampu menurunkan kekerasan mi non terigu. Klinmalai et al. (2017) menyebutkan bahwa penggunaan asam asetat dan kitosan mampu menurunkan kekerasan mi basah beras, terutama kekerasan mi yang disimpan 2 sampai 4 hari. Peneliti- 
an Subarna et al. (2012) menunjukkan bahwa penambahan 1\% GMS menghasilkan mi jagung dengan nilai kekerasan dan kekenyalan yang lebih rendah. Muhandri dan Subarna (2009) menunjukkan bahwa interaksi antara air dan $\mathrm{NaCl}$ juga mampu mempengaruhi sifat reologi mi jagung. Penambahan $70 \%$ air dan $2 \% \mathrm{NaCl}$ mampu menurunkan sifat kekerasan mi jagung hingga 1954,76 gF. Muhandri et al. (2013) melakukan penambahan $2 \%$ guar gum pada adonan mi jagung dan penambahan ini dapat menurunkan kekerasan mi hingga 2550,32 gF, namun panelis menyatakan bahwa penambahan guar gum menghasilkan mi jagung dengan warna kehitaman dan rasa pahit yang tidak disukai.

Propilen glikol alginat (PGA) merupakan salah satu bahan tambahan pangan hasil modifikasi alginat. Senyawa ini dapat dimanfaatkan dalam pembuatan mi berbasis non-terigu karena dapat berfungsi sebagai zat pengikat. FDA (2015) menyebutkan bahwa PGA merupakan salah satu bahan tambahan pangan jenis hidrokoloid yang memiliki kemampuan sebagai stabilizer, emulsifier, plastisizer dan sebagai zat pengikat. Huaisan et al. (2009) menyatakan bahwa penambahan bahan tambahan pangan yang bersifat hidrofilik seperti alginat dapat memberikan efek terhadap penurunan viskositas pada retrogradasi pati.

Terjadinya retrogradasi pati akan menyebabkan beberapa perubahan reologi pada produk pangan terutama pada produk-produk yang berbasis pati. Perubahan reologi pada produk mi pati teramati dengan terjadinya peningkatan kekerasan dan kelengketan. Retrogradasi pati terjadi karena terlepasnya amilosa saat proses gelatinisasi. Fraksi amilosa yang terlarut dapat berikatan satu sama lain sehingga dapat meningkatkan kekerasan mi. Penambahan PGA dalam pembuatan mi jagung diharapkan dapat menghasilkan mi dengan parameter fisik yang lebih baik.

Soy protein isolate (SPI) merupakan sumber protein nabati yang sering dimanfaatkan sebagai pensubtitusi dalam pembuatan produk pangan seperti meat analogue, gluten-free pasta, yoghurt dan masih banyak lagi. Penambahan SPI pada produk pangan bertujuan untuk meningkatkan kandungan gizi produk. Penambahan SPI juga bertujuan untuk memanfaatkan sifat fungsional yang dimiliki oleh SPI itu sendiri, yaitu sebagai bahan pengikat. Menurut hasil penelitian Detchewa et al. (2016) dalam pembuatan mi berbasis tepung beras dengan penambahan SPI, menunjukkan bahwa penambahan $5 \%$ SPI pada adonan mi menghasilkan penurunan KPAP dari 21,6 menjadi $17 \%$ dan juga penurunan nilai kelengketan dari 0,40 menjadi 0,22 N. Penambahan SPI pada adonan mi non terigu akan menyebabkan terbentuknya jaringan antara protein dan pati dimana jaringan ini dapat memerangkap pati yang telah tergelatinisasi sehingga dapat menurunkan lepasnya padatan selama pemasakan mi (Gopalakrishnan et al., 2011).

Penelitian tentang penggunaan PGA dan SPI pada pembuatan mi jagung belum dilakukan oleh peneliti. Penelitian ini bertujuan mengevaluasi efek penambahan propilen glikol alginat (PGA) dan soy protein isolate (SPI) terhadap parameter fisik dari mi jagung.

\section{BAHAN DAN METODE}

\section{Bahan}

Bahan utama yang digunakan untuk membuat mi jagung dalam penelitian ini adalah tepung jagung jenis BISI berukuran 80 mesh yang diperoleh dari PT. Matahari Corn Mill Kediri, soy protein isolate (SPI, Marksoy90) dari PT. Markindo Selaras, propilen glikol alginat (PGA) diperoleh dari PT. PAFA Mandiri.

\section{Karakterisasi tepung jagung}

Tepung yang diperoleh dari PT. Matahari Corn Mill, dianalisis untuk mengetahui karakteristiknya. Analisis meliputi distribusi ukuran partikel, proksimat dan kandungan amilosa.

\section{Pembuatan produk mi jagung}

Proses pembuatan mi jagung didasarkan pada metode Muhandri et al. (2011) dengan modifikasi. Modifikasi yang dilakukan adalah penggunaan tepung jagung lolos ayakan 80 mesh dan mongeringkan mi jagung menggunakan tray drier. Proses diawali dengan penimbangan semua bahan baku sesuai dengan formula (Tabel 1). Basis perhitungan formula didasarkan pada berat tepung jagung yakni sebesar 200 gram. Rancangan percobaan yang digunakan adalah Rancangan Acak Lengkap dengan 2 ulangan dan data dianalisis dengan uji ANNOVA dan dilanjutkan dengan uji Duncan menggunakan software SPSS versi 22. PGA yang ditambahkan terdiri dari lima taraf yaitu $0 ; 0,25 ; 0,5 ; 0,75$ dan $1 \%$ (basis berat tepung jagung). Penambahan SPI terdiri dari 3 taraf yaitu 0,5 dan 10\% (basis berat tepung jagung). Bahan dicampur dan diaduk dengan hand mixer (Philips, Indonesia) selama lima menit. Adonan dimasukkan ke dalam ekstruder pemasakpencetak (Labtech Engineering Co. Ltd., Thailand) dengan pengaturan suhu ekstruder $90^{\circ} \mathrm{C}$ dan kecepatan ulir $130 \mathrm{rpm}$. Untaian mi jagung yang masih basah dipotong sepanjang $40 \mathrm{~cm}$, dipisahkan antar untaian, dibentuk melingkar, kemudian dikeringanginkan menggunakan tray dryer (Armfield Horizontal Model, England) selama \pm 24 jam pada suhu ruang.

\section{Analisis distribusi ukuran tepung jagung (Hrncirova et al., 2013) \\ Tepung jagung dihomogenkan terlebih dahulu dengan menggunakan hand mixer (Philips,}


Indonesia) kemudian diambil sebanyak 100 gram diayak secara bertingkat mulai dari mesh 80,100 , dan 115 menggunakan vibrating screen, knob kecepatan vibrasi disetel pada skala 5 dengan lama pengayakan 30 menit. Pengukuran hanya dilakukan satu ulangan. Fraksi pada setiap ayakan ditimbang dan dihitung persentasenya. Data ini dimaksudkan untuk mengidentifikasi karakter bahan baku tepung jagung yang digunakan.

Tabel 1. Formula pembuatan mi jagung

\begin{tabular}{ccccc}
\hline Formula & $\begin{array}{c}\text { Tepung } \\
\text { Jagung }(\mathrm{g})\end{array}$ & $\begin{array}{c}\text { Air 70\% } \\
(\mathrm{g})\end{array}$ & $\begin{array}{c}\text { SPI } \\
(\%)\end{array}$ & $\begin{array}{c}\text { PGA } \\
(\%)\end{array}$ \\
\hline F1 & 200 & 140 & 0 & 0 \\
F2 & 200 & 140 & 0 & 0,25 \\
F3 & 200 & 140 & 0 & 0,5 \\
F4 & 200 & 140 & 0 & 0,75 \\
F5 & 200 & 140 & 0 & 1 \\
F6 & 200 & 140 & 5 & 0 \\
F7 & 200 & 140 & 5 & 0,25 \\
F8 & 200 & 140 & 5 & 0,5 \\
F9 & 200 & 140 & 5 & 0,75 \\
F10 & 200 & 140 & 5 & 1 \\
F11 & 200 & 140 & 10 & 0 \\
F12 & 200 & 140 & 10 & 0,25 \\
F13 & 200 & 140 & 10 & 0,5 \\
F14 & 200 & 140 & 10 & 0,75 \\
F15 & 200 & 140 & 10 & 1 \\
\hline
\end{tabular}

\section{Analisis proksimat}

Analisis kadar air metode oven (AOAC, 2005), analisis kadar abu metode pengabuan kering AOAC (2005), analisis kadar lemak Metode Soxhlet AOAC (2005), analisis protein Metode Kjeldahl AOAC (2005), analisis kadar karbohidrat (by difference).

\section{Analisis kadar amilosa (AOAC, 1995)}

Amilosa murni ditimbang sebanyak $40 \mathrm{mg}$ kemudian dimasukan ke dalam tabung reaksi, ditambahkan dengan $1 \mathrm{~mL}$ etanol 95\% (Merck, Jerman) dan $9 \mathrm{~mL} \mathrm{NaOH} 1 \mathrm{~N}$ (Merck, Jerman). Tabung reaksi berisi amilosa dipanaskan dalam air mendidih selama 10 menit sampai terbentuk gel. Gel yang terbentuk dipindahkan ke dalam labu takar $100 \mathrm{~mL}$. Dibuat seri pengenceran dengan cara memindahkan sebanyak 1, 2, 3, 4, dan $5 \mathrm{~mL}$ larutan gel ke dalam labu takar $100 \mathrm{~mL}$. Ke dalam masing-masing labu takar ditambahkan asam asetat $1 \mathrm{~N}$ (Merck, Jerman) masing-masing 0,$2 ; 0,4 ; 0,6 ; 0,8$ dan $1,0 \mathrm{~mL}$, lalu ditambahkan larutan iod sebanyak $2 \mathrm{~mL}$. Tahap selanjutnya adalah pengukuran intensitas warna biru yang terbentuk dengan spektrofotometer pada panjang gelombang $625 \mathrm{~nm}$.

Sampel ditimbang sebanyak $100 \mathrm{mg}$ kemudian ditambah dengan $1 \mathrm{~mL}$ etanol $95 \%$ dan $9 \mathrm{~mL} \mathrm{NaOH}$ $1 \mathrm{~N}$. Selanjutnya dipanaskan dalam air mendidih selama 10 menit sampai terbentuk gel. Gel yang terbentuk dipindahkan ke dalam labu takar $100 \mathrm{~mL}$, kemudian dikocok dan ditepatkan sampai tanda tera dengan akuades. Larutan tersebut dipipet sebanyak $5 \mathrm{~mL}$ dan dimasukan ke dalam labu takar $100 \mathrm{~mL}$, ditambahkan $1 \mathrm{~mL}$ asam asetat $1 \mathrm{~N}$ dan $2 \mathrm{~mL}$ larutan iod. Kemudian ditepatkan sampai tanda tera dengan air, dikocok dan didiamkan selama 20 menit. Tahap selanjutnya adalah pengukuran intensitas warna yang terbentuk dengan spektrofotometer pada panjang gelombang $625 \mathrm{~nm}$. Kadar amilosa sampel dihitung menggunakan formula berikut ini:

$$
\text { Kadar amilosa }=\frac{C \times V \times F P \times 100}{W}
$$

dimana, C adalah konsentrasi amilosa contoh dari kurva standar $(\mathrm{mg} / \mathrm{mL}), \mathrm{V}$ merupakan volume akhir contoh (100 mL), FP adalah faktor pengeceran (20 kali) dan $\mathrm{W}$ adalah berat contoh (mg).

\section{Analisis kehilangan padatan akibat pemasakan/ cooking loss (Kongkiattisak dan Songsermpong, 2012, dengan modifikasi)}

Modifikasi yang dilakukan dalam penentuan kehilangan padatan akibat pemasakan (KPAP), dilakukan dengan cara merebus $5 \mathrm{~g}$ mi dalam $150 \mathrm{~mL}$ air. Mi jagung direbus selama 10 menit, ditiriskan dan disiram air, kemudian ditiriskan kembali selama 5 menit. Mi ditimbang dan dikeringkan pada suhu $100^{\circ} \mathrm{C}$ sampai beratnya konstan, lalu ditimbang kembali. Disamping itu dilakukan juga pengukuran kadar air pada sampel sebanyak 5 gram. Pengukuran kadar air dilakukan untuk menghitung berat kering sampel. KPAP dihitung dengan rumus berikut:

$$
\operatorname{KPAP}=\frac{a-b}{a} \times 100 \%
$$

dimana, a adalah berat kering sampel sebelum direbus (g) dan b adalah berat kering sampel sesudah direbus $(g)$.

\section{Analisis elongasi menggunakan texture analyzer}

Analisis elongasi dilakukan menggunakan instrumen Texture Analyzer Stable Micro-System TAXT2i. Analisis dilakukan terhadap sampel mi jagung yang telah dimasak selama 10 menit. Analisis dilakukan dengan melilitkan satu untaian mi pada probe dengan jarak antar probe $2 \mathrm{~cm}$ dan kecepatan probe $0,3 \mathrm{~cm} / \mathrm{s}$. Persen elongasi dapat dihitung dengan cara:

Persen elongasi $=\frac{\text { Waktu putus sampel }(\mathrm{s}) \times 0,3 \mathrm{~cm} / \mathrm{s}}{2 \mathrm{~cm}} \times 100 \%$

\section{Texture profile analysis menggunakan texture analyzer}

Penentuan texture profile analysis (TPA) dilakukan dengan menggunakan Texture Analyzer. Prinsip analisis TPA adalah dengan menekan bahan de- 
ngan kecepatan penekanan yang konstan sehingga bahan akan mengalami deformasi. Pada analisis TPA penekanan diberikan sebanyak dua kali sehingga akan diperoleh hasil kurva dengan dua buah puncak yang menunjukkan hubungan antara gaya untuk mendeformasi dan waktu. Grafik pada Gambar 1 merupakan contoh kurva hasil analisis TPA. Area A1 merupakan luasan yang diperoleh pada penekanan pertama sedangkan A2 merupakan luasan yang diperoleh pada penekanan kedua. Nilai kekerasan ditunjukkan oleh absolute peak pada area A1 yang menunjukkan besarnya gaya yang diperlukan untuk mendeformasi bahan. Nilai kekenyalan diperoleh dengan menghitung perbandingan antara area A2 dengan area $\mathrm{A} 1$ yang menunjukkan seberapa besar produk dapat kembali ke kondisi semula setelah diberikan gaya pada penekanan pertama. Nilai kelengketan ditunjukkan oleh luasan area di bawah kurva yang merupakan area A3.

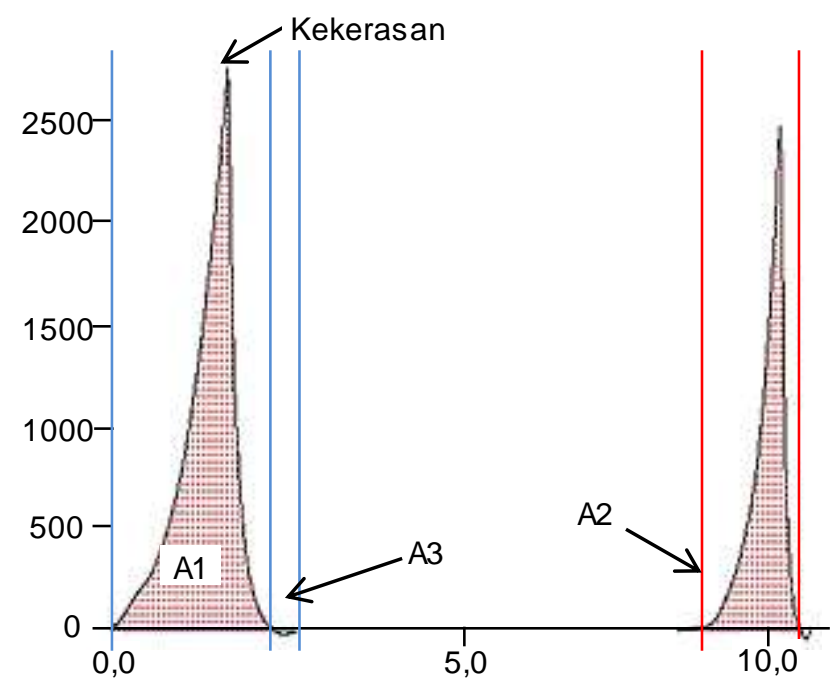

Keterangan: $\mathrm{A} 1=$ luas area pada penekanan pertama; $\mathrm{A} 2=$ luas area pada penekanan kedua; $A 3=$ luas area dibawah kurva

Gambar 1. Contoh kurva analisis profil tekstural

Untuk memperoleh data TPA, pada penelitian ini digunakan probe berbentuk silinder dengan diameter $35 \mathrm{~mm}$. Probe silinder dipilih karena sesuai dengan produk yang dianalisis yaitu agar dapat menekan seluruh permukaan mi secara merata. Pengukuran dilakukan dengan meletakkan dua untai mi di atas papan kompresi lalu ditekan oleh probe. Pengaturan mode untuk pengukuran TPA adalah pre test speed $2.0 \mathrm{~mm} / \mathrm{s}$, test speed $1.0 \mathrm{~mm} / \mathrm{s}$, post test speed $2.0 \mathrm{~mm} / \mathrm{s}$ dan rupture test distance $75 \%$.

\section{Analisis mutu sensori (Meilgaard et al., 2016)}

Analisis mutu sensori diperlukan untuk mengidentifikasi tingkat penerimaan panelis terhadap mutu mi jagung akibat penambahan SPI dan PGA. Mu- tu fisik mi jagung yang dipengaruhi oleh penambahan SPI dan PGA diharapkan disukai oleh panelis.

Analisis dilakukan terhadap sampel mi jagung rebus tanpa menggunakan saus. Jenis analisis sensori yang dilakukan adalah uji rating hedonik balance incomplete blocks, untuk parameter kekerasan, kelengketan, kekenyalan dan keseluruhan. Untuk keperluan uji ini digunakan skala hedonik dengan 6 (enam) tingkat kesukaan yaitu (1) sangat tidak suka, (2) tidak suka, (3) agak tidak suka, (4) agak suka, (5) suka, (6) sangat suka. Pemilihan skala kategori dengan nilai genap ini bertujuan untuk menghindari adanya poin netral yang biasanya cenderung akan dipilih oleh panelis. Jumlah panelis yang digunakan pada analisis ini sebanyak 35 orang panelis tidak terlatih.

\section{HASIL DAN PEMBAHASAN}

\section{Distribusi ukuran tepung jagung}

Pada label tepung jagung yang diperoleh dari PT. Matahari Corn Mill, dinyatakan bahwa tepung ini berukuran 80 mesh. Hasil uji menunjukkan jumlah tepung yang lolos ayakan 80 mesh tetapi tidak lolos ayakan 100 mesh yaitu 74,7\%, sedangkan yang tertahan pada ayakan 80 mesh sebanyak 4,6\% (Gambar 2). Hasil uji memperlihatkan bahwa tepung jagung produksi PT. Matahari Corn Mill yang digunakan dalam penelitian ini telah memenuhi persyaratan SNI 01-3727 (1995) dari sisi keseragaman ukuran partikel. Standar ini menyatakan bahwa jumlah partikel yang lolos ayakan 80 mesh minimal sebesar $70 \%$.

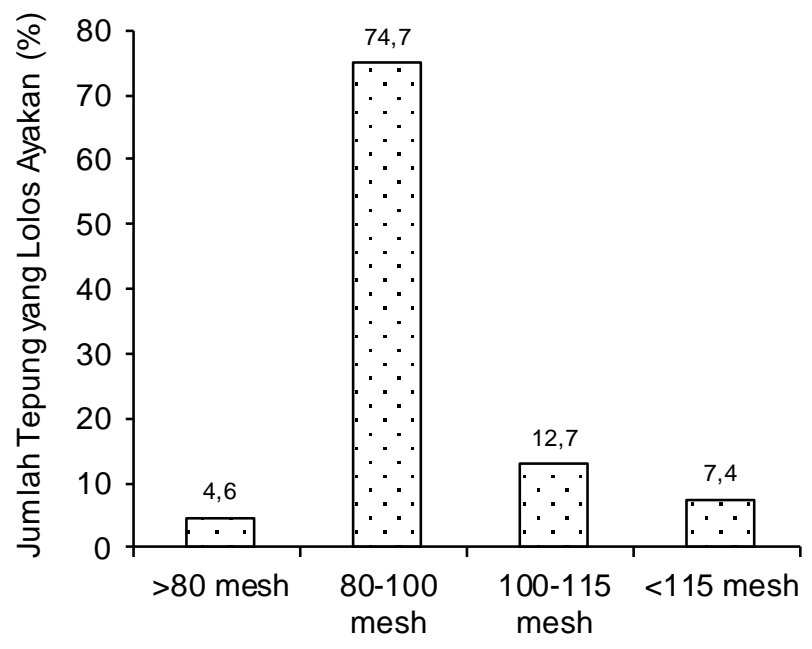

Gambar 2. Grafik Distribusi Ukuran Tepung jagung

Ukuran partikel tepung jagung yang digunakan dalam penelitian ini relatif seragam dan berukuran kecil sehingga cocok untuk pembuatan mi jagung, karena ukuran partikel yang semakin kecil meningkatkan penyerapan air (karena luas permukaan 
yang besar), sehingga mampu meningkatkan kekerasan adonan dan elastisitas produk mi (Jung et al., 2017). Darmajana et al. (2016) dalam penelitianya membandingkan mi jagung yang dibuat dengan tepung berukuran 40, 60 dan 100 mesh, hasil penelitian tersebut menunjukkan bahwa semakin kecil ukuran partikel tepung, mi jagung yang dihasilkan akan memiliki kualitas yang lebih baik.

\section{Karakteristik kimia tepung jagung}

Karakteristik kimia tepung jagung yang digunakan dalam penelitian ini diketahui melalui analisis proksimat yang meliputi kadar air, abu, protein, lemak, karbohidrat dan amilosa. Hasil analisis menunjukkan bahwa tepung jagung uji telah memenuhi standar SNI 01-3727 (BSN, 1995), untuk parameter kadar air dan kadar abu. SNI 01-3727 (BSN, 1995) menyatakan bahwa kadar air maksimal tepung jagung (\% bb) sebesar $10 \%$ sedangkan untuk kadar abu (\% bb) maksimal sebesar 1,5\%. Daftar lengkap hasil uji proksimat diperlihatkan pada Tabel 2.

Tabel 2. Karakteristik kimia tepung jagung

\begin{tabular}{cc}
\hline Parameter & $(\% \mathrm{bb})$ \\
\hline Kadar air & $9,05 \pm 0,02$ \\
Kadar abu & $0,43 \pm 0,02$ \\
Kadar lemak & $1,68 \pm 0,01$ \\
Kadar protein & $5,31 \pm 0,00$ \\
Karbohidrat & $83,53 \pm 0,02$ \\
Kadar amilosa & $28,07 \pm 0,04$ \\
\hline
\end{tabular}

Lemak yang terkandung pada tepung jagung uji adalah sebesar $1,68 \%$, hasil ini sejalan dengan hasil penelitian Muhandri et al. (2012) yaitu kandungan lemak tepung jagung lokal berkisar antara 1,62\%$1,85 \%$. Kadar amilosa sebesar $28,07 \%$ menunjukkan bahwa tepung jagung uji tergolong sebagai tepung jagung dengan kandungan amilosa sedang/ normal (Muhandri dan Subarna, 2009). Muhandri et al. (2012) menyatakan bahwa tepung jagung varietas Bisma, Lamuru dan Arjuna dengan kandungan amilosa sebanyak 27,14-27,68\% mampu menghasilkan mi jagung basah dengan kualitas yang baik. Secara teori, dari tepung jagung uji akan dapat dihasilkan mi jagung dengan kulitas yang baik.

\section{Kehilangan padatan akibat pemasakan (KPAP)}

Kehilangan padatan akibat pemasakan atau cooking loss merupakan banyaknya padatan yang keluar atau hilang terlarut ke dalam air selama proses pemasakan. KPAP merupakan parameter kualitas yang penting untuk produk mi. Semakin rendah nilai KPAP menunjukkan bahwa mi yang diuji memiliki tekstur yang kokoh dan homogen (Muhandri dan Subarna, 2009).

Nilai KPAP mi jagung yang dibuat dari tepung uji memiliki nilai yang berkisar antara 9,56-21,76\% (Tabel 3). Hasil ANOVA menunjukkan bahwa terda- pat interaksi antara perlakuan PGA dan SPI, dan pengaruh interaksi ini terhadap nilai KPAP mi jagung adalah signifikan $(P<0,05)$. Secara umum, peningkatan taraf penambahan SPI pada adonan mi mampu menurunkan nilai KPAP mi jagung. Taraf penambahan PGA sebesar 1\%, penambahan SPI sebesar $10 \%$ akan memberikan nilai KPAP yang lebih rendah dibandingkan penambahan SPI sebanyak $5 \%$ atau tanpa SPI.

Tabel 3. Nilai KPAP (\%) mi jagung matang pada berbagai kombinasi jumlah PGA dan SPI

\begin{tabular}{cccc}
\hline Formula & \multicolumn{3}{c}{ SPI $(\%)$} \\
\cline { 2 - 4 } PGA & 0 & 5 & 10 \\
\hline$\%)$ & & $17,02 \pm 0,01^{\mathrm{ef}}$ & $15,94 \pm 0,85^{\text {def }}$ \\
0,25 & $17,29 \pm 0,30^{\mathrm{f}}$ & $14,54 \pm 0,16^{\text {cd }}$ & $12,38 \pm 0,92^{\mathrm{bc}}$ \\
0,50 & $15,90 \pm 0,37^{\text {def }}$ & $15,72 \pm 0,38^{\text {def }}$ & $12.54 \pm 0,39^{\mathrm{bc}}$ \\
0,75 & $13,94 \pm 0,25^{\mathrm{cd}}$ & $14,92 \pm 0,25^{\mathrm{de}}$ & $10,85 \pm 1,05^{\mathrm{ab}}$ \\
1,00 & $17,63 \pm 0,10^{\mathrm{f}}$ & $13,85 \pm 0,84^{\text {cd }}$ & $9,56 \pm 0,21^{\mathrm{a}}$ \\
\hline
\end{tabular}

Penambahan PGA secara umum mampu menurunkan nilai KPAP. Sodium alginat berperan dalam distribusi air yang lebih merata dalam adonan, baik di bagian tengah maupun di permukaan adonan (Pan et al., 2016), sehingga gelatinisasi saat terkena panas dan pelumatan adonan pada saat proses shear stress dalam ekstruder terjadi lebih merata. Hal inilah yang menyebabkan kehilangan padatan selama proses pemasakan dapat dicegah dan nilai KPAP menjadi lebih rendah.

Formula dengan penambahan kombinasi SPI dan PGA menghasilkan efek penurunan nilai KPAP yang lebih besar. Menurut Gopalakrishnan et al. (2011) penambahan SPI pada adonan mi berbasis tepung non terigu akan menyebabkan terbentuknya jaringan antara protein dan pati dimana jaringan ini dapat memerangkap komponen-komponen adonan sehingga dapat menurunkan lepasnya padatan selama pemasakan mi. Dickinson dan Walstra (2011) menyatakan bahwa adanya interaksi antara protein pada SPI dan polisakarida pada PGA yang akan membentuk ikatan kovalen yang kokoh sehingga bisa menahan keluarnya komponen-komponen saat dimasak.

\section{Elongasi}

Elongasi adalah pertambahan panjang mi akibat gaya tarikan. Mi dengan elongasi tinggi menunjukkan karakteristik mi yang tidak mudah putus (Muhandri dan Subarna, 2009). Nilai elongasi mi jagung berkisar antara 125,84-269,34\% (Tabel 4). Hasil ANOVA menunjukkan interaksi antara perlakuan PGA dan SPI punya pengaruh signifikan $(P<0,05)$ terhadap elongasi mi jagung. Penggunaan PGA saja tanpa penambahan SPI dan kombinasi SPI pada level $10 \%$ dengan PGA pada level 0,25$1 \%$ kurang efektif untuk meningkatkan nilai elongasi 
karena menghasilkan nilai elongasi yang lebih rendah.

Tabel 4. Nilai elongasi (\%) mi jagung pada berbagai kombinasi jumlah PGA dan SPI

\begin{tabular}{cccc}
\hline $\begin{array}{c}\text { Formula } \\
\text { PGA }\end{array}$ & \multicolumn{3}{c}{ SPI $(\%)$} \\
\cline { 2 - 4 }$(\%)$ & 0 & 5 & 10 \\
\hline 0 & $125,84 \pm 18,74^{\text {a }}$ & $152,02 \pm 1,41^{\text {av }}$ & $183,24 \pm 11,82^{\text {ocu }}$ \\
0,25 & $156,46 \pm 11,23^{\text {au }}$ & $201,04 \pm 1,16^{\text {cue }}$ & $195,24 \pm 2,22^{\text {cue }}$ \\
0,50 & $151,76 \pm 4,37^{\text {au }}$ & $237,47 \pm 23,18^{1}$ & $229,86 \pm 3,53^{\text {el }}$ \\
0,75 & $158,96 \pm 4,23^{\text {au }}$ & $220,46 \pm 4,42^{\text {el }}$ & $213,31 \pm 10,05^{\text {uel }}$ \\
1,00 & $167,40 \pm 10,13^{\text {uv }}$ & $269,34 \pm 2,04^{y}$ & $226,54 \pm 15,31^{\text {el }}$ \\
\hline
\end{tabular}

Pada taraf SPI $5 \%$, peningkatan taraf penggunaan PGA meningkatkan elongasi secara nyata. Secara keseluruhan nilai elongasi tertinggi adalah pada formula dengan penambahan 5\% SPI dan 1\% PGA yaitu sebesar $269,34 \%$. Hal ini menunjukkan kombinasi perlakuan pada taraf tersebut adalah yang paling optimal untuk meningkatkan nilai elongasi. Penggunaan PGA 1\% mampu meningkatkan persen elongasi disebabkan karena adanya interaksi antara PGA dan pati berupa ikatan ester antara gugus hidroksil pada amilopektin dari pati dengan gugus asam karboksilat dari PGA (Li et al., 2008) yang akan membentuk kompleks yang bersifat kokoh.

Fenomena ini menghasilkan mi yang lebih kuat dan tidak mudah putus ketika ditarik sehingga nilai elongasinya semakin tinggi. Menurut Dickinson dan Walstra (2011) adanya interaksi antara protein pada SPI dan polisakarida pada PGA akan membentuk kompleks tiga dimensi yang kokoh sehingga mi akan lebih kuat dan tidak mudah putus ketika mengalami tarikan.

\section{Kekerasan}

Nilai kekerasan menggambarkan daya tahan suatu produk terhadap tekanan. Kekerasan pada mi dapat diakibatkan oleh proses retrogradasi pati, yaitu terbentuknya ikatan antara amilosa-amilosa yang telah terdispersi ke dalam air. Nilai kekerasan mi berkisar antara 2778-6379 gF (Tabel 5). Interaksi antara perlakuan PGA dan SPI memberikan pengaruh yang signifikan terhadap kekerasan $(P<0,05)$. Pada level SPI $0 \%$, trend data menunjukkan adanya penurunan nilai kekerasan mi jagung seiring peningkatan jumlah PGA. Kondisi sebaliknya terjadi pada level SPI 5 dan 10\%, dimana peningkatan penambahan PGA justru meningkatkan nilai kekerasan mi jagung. Penurunan kekerasan mi jagung akibat penambahan PGA disebabkan oleh kemampuan PGA dalam menahan air, sehingga mi menjadi lebih plastis. Hal ini sejalan dengan penelitian Huaisan et al. (2009) yang menyatakan bahwa penggunaan alginat dapat menurunkan breakdown viscosity dan menurunkan kekerasan gel dari pati beras.

Hasil penelitian mi jagung sebelumnya menggunakan ekstruder pemasak-pencetak (Muhandri et al., 2011) menghasilkan mi dengan kekerasan yang tinggi yaitu sebesar 3039,79 gF dan kurang disukai konsumen. Penggunaan PGA sampai level $1 \%$ sebagai rheological modifier pada mi jagung efektif untuk menurunkan tingkat kekerasannya. Peningkatan penggunaan SPI sendidri (0\% PGA) meningkatkan kekerasan, tetapi peningkatan kekerasan mi jagung lebih nyata pada formula yang ditambah PGA. Adanya interaksi antara SPI dan PGA menyebabkan mi jagung menjadi lebih rigid.

Tabel 5. Nilai kekerasan $(\mathrm{gF}) \mathrm{mi}$ jagung pada berbagai kombinasi jumlah PGA dan SPI

\begin{tabular}{cccc}
\hline Formula & \multicolumn{3}{c}{ SPI (\%) } \\
\cline { 2 - 4 } PGA (\%) & 0 & 5 & 10 \\
\hline 0 & $2978 \pm 3^{\mathrm{d}}$ & $3240 \pm 241^{\mathrm{j}}$ & $3988 \pm 4^{\mathrm{f}}$ \\
0,25 & $2824 \pm 23^{\mathrm{cd}}$ & $4890 \pm 43^{\mathrm{g}}$ & $5125 \pm 6^{\mathrm{h}}$ \\
0,50 & $2631 \pm 52^{\mathrm{bc}}$ & $5436 \pm 135^{\mathrm{i}}$ & $5810 \pm 36^{\mathrm{j}}$ \\
0,75 & $2510 \pm 34^{\mathrm{ab}}$ & $4751 \pm 103^{\mathrm{g}}$ & $5455 \pm 28^{\mathrm{i}}$ \\
1,00 & $2346 \pm 21^{\mathrm{a}}$ & $5728 \pm 149^{\mathrm{j}}$ & $6379 \pm 2^{\mathrm{k}}$ \\
\hline
\end{tabular}

\section{Kekenyalan}

Kekenyalan merupakan kemampuan produk untuk kembali ke bentuk semula setelah mendapatkan gaya tekan. Pengukuran ini berhubungan dengan evaluasi sensori mi saat digigit. Pada mi terigu, gluten gandum berperan dalam membentuk adonan dengan massa yang elastic-cohessive. Pada mi non-terigu diperlukan adanya suatu zat pengikat sehingga dapat menghasilkan adonan mi dengan massa yang elastic-cohessive (Subarna et al., 2012).

Nilai kekenyalan mi berkisar antara 0,49-0,67 (Tabel 6). Interaksi antara perlakuan PGA dan SPI memberikan pengaruh yang signifikan $(P<0,05)$ terhadap kekenyalan mi jagung. Penambahan PGA 0,75\% mampu meningkatkan kekenyalan mi jagung yang tidak ditambah SPI. Pada taraf penambahan SPI 5 dan $10 \%$, penambahan PGA 0,25\% sudah dapat meningkatkan kekenyalan mi jagung. Pada taraf penambahan PGA 0,50 dan $1 \%$, penambahan SPI tidak menyebabkan perubahan kekenyalan secara nyata.

Tabel 6. Nilai kekenyalan mi jagung pada berbagai kombinasi jumlah PGA dan SPI

\begin{tabular}{cccc}
\hline Formula & \multicolumn{3}{c}{ SPI $(\%)$} \\
\cline { 2 - 4 }$(\%)$ & 0 & 5 & 10 \\
\hline 0 & $0,56 \pm 18,74^{\mathrm{b}}$ & $0,57 \pm 1,41^{\mathrm{b}}$ & $0,49 \pm 11,82^{\mathrm{a}}$ \\
0,25 & $0,56 \pm 11,23^{\mathrm{b}}$ & $0,67 \pm 1,16^{\mathrm{d}}$ & $0,65 \pm 2,22^{\mathrm{cd}}$ \\
0,50 & $0,59 \pm 4,37^{\mathrm{bc}}$ & $0,65 \pm 23,18^{\mathrm{cd}}$ & $0,64 \pm 3,53^{\mathrm{cd}}$ \\
0,75 & $0,64 \pm 4,23^{\mathrm{cd}}$ & $0,66 \pm 4,42^{\mathrm{cd}}$ & $0,66 \pm 10,05^{\mathrm{d}}$ \\
1,00 & $0,63 \pm 10,13^{\mathrm{cd}}$ & $0,67 \pm 2,04^{\mathrm{d}}$ & $0,66 \pm 15,31^{\mathrm{d}}$ \\
\hline
\end{tabular}

PGA akan berperan sebagai zat pengikat dalam adonan mi jagung. Adanya peningkatan nilai kekenyalan pada mi jagung dikarenakan kemampuan PGA sebagai zat pengikat mampu berinteraksi dengan makromolekul seperti karbohidrat dan protein. Kemampuan pengikatan ini berkaitan dengan pem- 
bentukan gel. Saat pembentukan gel, terjadi ikatanikatan silang dan terbentuklah struktur jala tiga dimensi yang dapat memerangkap air sehingga akan terbentuk tekstur yang kenyal, tetapi ikatan yang terlalu kuat menyebabkan produk menjadi lebih rigid yang ditunjukkan dengan kekerasan yang tinggi dan kurang kenyal.

\section{Kelengketan}

Kelengketan merupakan daya rekat yang ditunjukkan dengan besarnya gaya yang dibutuhkan untuk menarik bagian pangan dan memisahkannya dari lempeng kompresi. Kelengketan merupakan parameter yang mendukung mutu mi jagung, dimana dikehendaki mi jagung yang memiliki tingkat kelengketan yang rendah. Nilai kelengketan mi jagung berkisar antara $(-1,05)-(-6,21) \mathrm{gF}$. Interaksi antara perlakuan PGA dan SPI memberikan pengaruh yang signifikan $(P<0,05)$ terhadap nilai kelengketan mi jagung (Tabel 7).

Tabel 7. Nilai kelengketan (gF) mi jagung pada berbagai kombinasi jumlah PGA dan SPI

\begin{tabular}{cccc}
\hline $\begin{array}{c}\text { Formula } \\
\text { PGA } \\
(\%)\end{array}$ & 0 & 5 & 10 \\
\cline { 2 - 4 } & & \multicolumn{3}{c}{ SPI $(\%)$} \\
\hline 0 & $-6,21 \pm 0,16^{\mathrm{a}}$ & $-4,65 \pm 0,10^{\mathrm{bc}}$ & $-4,39 \pm 0,12^{\mathrm{bc}}$ \\
0,25 & $-4,94 \pm 0,23^{\mathrm{b}}$ & $-4,64 \pm 0,52^{\mathrm{bc}}$ & $-4,20 \pm 0,16^{\mathrm{c}}$ \\
0,50 & $-2,09 \pm 0,07^{\mathrm{d}}$ & $-1,95 \pm 0,11^{\text {de }}$ & $-2,18 \pm 0,09^{\mathrm{d}}$ \\
0,75 & $-1,42 \pm 0,21^{\text {ef }}$ & $-2,18 \pm 0,04^{\mathrm{d}}$ & $-1,22 \pm 0,08^{\dagger}$ \\
1,00 & $-1,14 \pm 0,06^{\dagger}$ & $-2,03 \pm 0,35^{\mathrm{d}}$ & $-1,05 \pm 0,02^{\dagger}$ \\
\hline
\end{tabular}

Penambahan PGA tanpa SPI menurunkan nilai kelengketan mi jagung secara drastis. Peningkatan taraf penambahan PGA sampai $0,75 \%$ mampu menurunkan nilai kelengketan. Penambahan SPI sendiri tanpa PGA, mampu menurunkan kelengketan, tetapi pada adonan yang menggunakan PGA, dam- pak penurunan kelengketan mi akibat penambahan SPI, tidak terlalu besar.

Penggunaan PGA secara tunggal mampu menurunkan tingkat kelengketan dari mi jagung karena kemampuan PGA sebagai zat pengikat mampu membentuk kompleks yang stabil dengan pati dan dapat mencegah terlepasnya amilosa selama proses gelatinisasi sehingga dapat menurunkan tingkat kelengketan dari mi. Pada formula dengan penambahan PGA dan SPI secara bersamaan, penurunan nilai kelengketan ini disebabkan adanya interaksi antara protein pada SPI dan polisakarida yang terdapat pada PGA yang akan membentuk suatu ikatan kovalen yang bersifat kokoh (Dickinson dan Walstra, 2011) kedua bahan ini akan bersinergi menghasilkan sifat pengikat yang baik dan mencegah terlepasnya amilosa selama proses gelatinisasi sehingga nilai kelengketan dapat diturunkan, namun kekerasan mi jagung meningkat signifikan.

\section{Penerimaan sensori panelis}

Uji rating hedonik ini dilakukan untuk mendapatkan respon berupa tingkat kesukaan dari panelis terhadap atribut produk serta mendapatkan sampel dengan kombinasi faktor perlakuan yang paling disukai, juga hubungannya dengan nilai tekstur objektif. Tabel 8 menunjukkan bahwa pada atribut kekerasan, formula yang memiliki skor tingkat penerimaan tertinggi adalah formula $\mathrm{F3}$ yaitu sebesar 5,23 (suka hingga sangat suka). Formula F3 memiliki nilai kekerasan yang diukur secara objektif sebesar $2631,75 \mathrm{gF}$. Nilai kesukaan ini tidak berbeda nyata $(P>0,05)$ dengan formula F1-F5, F7-F9 dan F13. Secara umum penambahan SPI dan PGA sampai level $5 \%$ SPI dan 0,75\% PGA akan menghasilkan mi jagung yang disukai konsumen, namun penambahan pada level yang lebih tinggi sampai $10 \%$ SPI dan 1\% PGA akan menurunkan penerimaanya.

Tabel 8. Data atribut sensori mi jagung

\begin{tabular}{|c|c|c|c|c|}
\hline \multirow{2}{*}{ Perlakuan } & \multicolumn{4}{|c|}{ Rating Kesukaan Panelis } \\
\hline & Kekerasan & Kekenyalan & Kelengketan & Overall \\
\hline F1 & $4,28^{D C}$ & $4,57^{\mathrm{aDC}}$ & $4,57^{\mathrm{a}}$ & $4,85^{\text {DCa }}$ \\
\hline $\mathrm{F} 2$ & $4,57^{\mathrm{DC}}$ & $4,71^{\mathrm{adc}}$ & $5,14^{\mathrm{a}}$ & $5,14^{\mathrm{ca}}$ \\
\hline F3 & $5,28^{\mathrm{C}}$ & $5,00^{\mathrm{C}}$ & $4,43^{\mathrm{a}}$ & $5,57^{\mathrm{a}}$ \\
\hline F4 & $4,71^{\mathrm{DC}}$ & $4,28^{\mathrm{adoc}}$ & $4,57^{\mathrm{a}}$ & $5,57^{\mathrm{a}}$ \\
\hline F5 & $4,42^{\mathrm{DC}}$ & $4,43^{\mathrm{axc}}$ & $4,43^{a}$ & $4,71^{\mathrm{Dca}}$ \\
\hline F6 & $4,00^{\circ}$ & $4,43^{\mathrm{adc}}$ & $4,71^{\mathrm{a}}$ & $4,71^{\mathrm{oca}}$ \\
\hline F7 & $4,28^{\mathrm{DC}}$ & $4,14^{\mathrm{axc}}$ & $4,57^{\mathrm{a}}$ & $4,00^{\mathrm{axc}}$ \\
\hline F8 & $4,71^{\mathrm{DC}}$ & $4,85^{\mathrm{DC}}$ & $5,00^{\mathrm{a}}$ & $5,14^{\mathrm{ca}}$ \\
\hline F9 & $4,14^{\mathrm{DC}}$ & $4,00^{\text {adc }}$ & $4,85^{\mathrm{a}}$ & $4,14^{\mathrm{adc}}$ \\
\hline F10 & $4,00^{\mathrm{D}}$ & $4,00^{\mathrm{axc}}$ & $5,00^{\mathrm{a}}$ & $4,00^{\mathrm{axc}}$ \\
\hline $\mathrm{F} 11$ & $3,86^{\mathrm{D}}$ & $4,14^{\mathrm{anc}}$ & $4,28^{\mathrm{a}}$ & $4,00^{\mathrm{adc}}$ \\
\hline F12 & $3,57^{\mathrm{D}}$ & $3,57^{\text {ao }}$ & $4,43^{a}$ & $3,71^{\text {ad }}$ \\
\hline F13 & $4,43^{\mathrm{DC}}$ & $3,85^{\mathrm{adc}}$ & $4,43^{\mathrm{a}}$ & $4,00^{\mathrm{adc}}$ \\
\hline F14 & $3,71^{\mathrm{D}}$ & $3,43^{\mathrm{a}}$ & $4,14^{\mathrm{a}}$ & $3,71^{\text {a }}$ \\
\hline F15 & $2,57^{\mathrm{a}}$ & $3,57^{\text {ad }}$ & $4,43^{\mathrm{a}}$ & $3,28^{a}$ \\
\hline
\end{tabular}

Keterangan: Skala hedonik rentang 1 (sangat tidak suka) sampai 6 (sangat suka). ${ }^{\mathrm{a}-\mathrm{c}}=$ Angka-angka pada kolom yang sama diikuti oleh huruf yang berbeda, berbeda nyata $(P<0,05)$ 
Hasil ini sejalan dengan pengukuran objektif yang menunjukkan bahwa pada level 5 dan $10 \%$ SPI, peningkatan penambahan jumlah PGA akan meningkatkan kekerasan mi. Formula F15 memiliki skor tingkat kesukaan terendah yaitu 2,57. Berdasarkan pengujian kekerasan secara objektif F15 diketahui memiliki nilai kekerasan tertinggi yaitu sebesar 6379,92 gF.

Tingkat penerimaan tertinggi pada atribut kekenyalan adalah formula F3 dengan skor 5,00 (suka). Formula 3 memiliki nilai kekenyalan yang diukur secara objektif sebesar 0,59 . Secara umum panelis tidak menyukai mi dengan tingkat kekenyalan yang tinggi. Hal ini disebabkan mi yang terlalu kenyal akan susah ketika di kunyah. Penerimaan panelis tidak menunjukkan perbedaan yang signifikan terhadap atribut kelengketan mi jagung. Hal ini menunjukkan bahwa penambahan SPI dan PGA tidak mempengaruhi atribut kelengketan secara sensori.

Hasil ANOVA kesukaan mi jagung secara keseluruhan menunjukkan formula dengan tingkat penerimaan tertinggi secara keseluruhan adalah formula 3 dan 4 dengan skor yang sama yaitu 5,57. Berdasarkan hasil tersebut menunjukkan bahwa penambahan SPI dan PGA sampai level 5\% SPI dan 0,5\% PGA menghasilkan mi jagung yang disukai konsumen secara keseluruhan, namun penambahan pada level yang lebih tinggi sampai level $10 \%$ SPI dan $1 \%$ PGA akan cenderung menurunkan tingkat penerimaanya.

Formula dengan tingkat peneriman tertinggi adalah formula F3 yaitu dengan skor kekerasan 5,28 , skor kekenyalan 5,00, skor kelengketan 4,42 dan skor secara keseluruhan 5,57. Formula F3 dibuat dengan penambahan 0,5\% PGA dan tanpa penambahan SPI.

\section{KESIMPULAN}

Penggunaan propilen glikol alginat (PGA) dan soy protein isolate (SPI) sebagai rheological modifier dapat mempengaruhi sifat reologi mi jagung. Interaksi antara perlakuan PGA dan SPI memberikan pengaruh yang signifikan terhadap kelima respon yang diamati. Penggunaan PGA secara tunggal mampu menurunan nilai KPAP, kekerasan dan kelengketan serta meningkatkan kekenyalan dan elongasi mi jagung. Penggunaan SPI secara tunggal dapat menurunkan KPAP, kelengketan dan kekenyalan serta meningkatkan kekerasan dan elongasi mi jagung.

Formula yang paling disukai berdasarkan uji organoleptik adalah formula 3 yaitu yang dibuat dengan penambahan 0,50\% PGA tanpa penambahan SPI. Formula ini memiliki nilai kekerasan yang relatif rendah yaitu sebesar $2631 \mathrm{gF}$, KPAP 15,90\%, kekenyalan sebesar 0,59 dan kelengketan sebesar -2,09 $\mathrm{gF}$.

\section{DAFTAR PUSTAKA}

[AOAC] Association of Official Analytical Chemist. 2005. Official Methods of Analysis. Arlington, AOAC International.

[BSN] Badan Standar Nasional. 1995. Standar Nasional Indonesia: Syarat Mutu Tepung Jagung. Jakarta (ID): Badan Standar Nasional.

Detchewa $P$, Thongnam $M$, Jane J, Naivikul $O$. 2016. Preparation of gluten-free rice spaghetti with soy protein isolate using twin-screw extrusion. J Food Sci Technol 53: 3485-3494. DOI: 10.1007/s13197-016-2323-8.

Darmajana DA, Ekafitri R, Kumalasari R, Indrianti N. 2016. Pengaruh variasi ukuran partikel tepung jagung terhadap karakteristik fisikokimia mi jagung instant. J Pangan 5: 1-12.

Gopalakrishnan J, Menon R, Padmaja G, Sajeev MS, Moorthy SN. 2011. Nutritional and functional characteristic of protein-fortified pasta from sweet potato. Food Nutr Sci 2: 944-955. DOI: 10.4236/fns.2011.29129.

Klinmalai P, Hagiwara T, Sakiyama T, Ratanasumawong S. 2017. Chitosan effects on physical properties, texture, and microstructure of flat rice noodles. LWT-Food Sci Technol 76: 117-123. DOI: 10.1016/j.Iwt.2016.10.052.

Huaisan K, Uriyapongson J, Rayas-Duarte P, Alli I, Srijesdaruk V. 2009. Effect of food additives on rheological and textural properties of frozen high amylose rice starch gels. Int J Food Prop 12: 145-161. DOI: 10.1080/1094291080225 2015.

Hrncirova M, Pospisil J, Michal S. 2013. Size analysis of solid particles using laser diffraction and sieve analysis. Engineer Mechan 20: 309-318.

Jung $\mathrm{H}$, Cho SJ, Pan C, Yoon WB. 2017. Rheological and microstructural properties of noodle dough with purple-fleshedpotato (Solanum tuberosum L.) flours: grinding kinetics and effects of particlesize. CyTA-J Food 16: 165171. DOI: 10.1080/19476337.2017.1366950.

Kongkiattisak P, Songsermpong S. 2012. Effect of temperature and velocity of drying air on kinetics, quality and energy consumption in drying process of rice noodles. Kasetsart J Nat Sci 46: 603-619.

Li Y, Shoemaker CF, Ma J, Shen X, Zhong F. 2008. Paste viscosity of rice starches of different amylose content and carboxymethylcellulose formed by dry heating and the physical properties of their films. Food Chem 109: 616-623. DOI: 10. 1016/j.foodchem.2008.01.023. 
Liu Y, Pan H, Liao T, Zhu B, Li Z, Wu J, Li Y, Cai J, Wang M. 2017. Combination of propylene glycol alginate and lauric acid on water retention and mechanical properties of soy protein isolate-based films. J Braz Chem Soc 28: 23652374. DOI: 10.21577/0103-5053.20170090.

Meilgaard M, Civillie GV, Carr BT. 2016. Sensory Technique Evaluation $5^{\text {th }}$ Ed. 271-280. CRC Press LLC, Florida (USA).

Muhandri T, Subarna. 2009. Pengaruh kadar air, $\mathrm{NaCl}$, dan jumlah passing terhadap karakteristik reologi mi jagung. J Teknol Industri Pangan 20: 71-77.

Muhandri T, Ahza AB, Syarief R, Sutrisno. 2011. Optimasi proses ekstrusi mi jagung dengan metode respon permukaan. J Teknol Industri $\mathrm{Pa}$ ngan 22: 97-104.

Muhandri T, Zulkhaiar H, Subarna, Nurtama B. 2012. Komposisi kimia tepung jagung varietas unggul lokal dan potensinya untuk pembuatan mi jagung menggunakan ekstruder pencetak. J Sains Terapan 2: 16-31.
Muhandri T, Subarna, Palupi NS. 2013. Karakteristik mi basah jagung akibat pengaruh laju pengumpanan dan penambahan guar gum. J Teknol Industri Pangan 24: 110-114. 10.6066/jtip.2013. 24.1.110.

Pan ZL, Ai ZL, Wang T, Wang YH, Zhang XL. 2016. Effect of hydrocolloids on the energy consumption and quality of frozen noodles. J Food Sci Technol 53: 2414-2421. DOI: 10.1007/s13197016-2217-9.

Subarna, Muhandri T, Nurtama B, Fierliyanti AS. 2012. Peningkatan mutu mi kering jagung dengan penerapan kondisi optimum proses dan penambahan monogliserida. J Teknol Industri Pangan 23: 146-152. DOI: 10.6066/jtip.2012. 23.2.146.

Subarna, Muhandri T. 2013. Pembuatan mi jagung kering dengan metode kalendering. J Teknol Industri Pangan 24: 75-80. DOI: 10.6066/jtip. 2013.24.1.75. 